\title{
Evaluation of the effects of ultraviolet light on bacterial contaminants inoculated into whole milk and colostrum, and on colostrum immunoglobulin $\mathrm{G}$
}

\author{
R. V. Pereira, M. L. Bicalho, V. S. Machado, S. Lima, A. G. Teixeira, L. D. Warnick, and R. C. Bicalho ${ }^{1}$ \\ Department of Population Medicine and Diagnostic Sciences, College of Veterinary Medicine, Cornell University, Ithaca, NY 14853
}

\begin{abstract}
Raw milk and colostrum can harbor dangerous microorganisms that can pose serious health risks for animals and humans. According to the USDA, more than $58 \%$ of calves in the United States are fed unpasteurized milk. The aim of this study was to evaluate the effect of UV light on reduction of bacteria in milk and colostrum, and on colostrum IgG. A pilot-scale UV light continuous (UVC) flow-through unit $\left(45 \mathrm{~J} / \mathrm{cm}^{2}\right)$ was used to treat milk and colostrum. Colostrum and sterile whole milk were inoculated with Listeria innocua, Mycobacterium smegmatis, Salmonella serovar Typhimurium, Escherichia coli, Staphylococcus aureus, Streptococcus agalactiae, and Acinetobacter baumannii before being treated with UVC. During UVC treatment, samples were collected at 5 time points and bacteria were enumerated using selective media. The effect of UVC on IgG was evaluated using raw colostrum from a nearby dairy farm without the addition of bacteria. For each colostrum batch, samples were collected at several different time points and IgG was measured using ELISA. The UVC treatment of milk resulted in a significant final count $(\log \mathrm{cfu} / \mathrm{mL})$ reduction of Listeria monocytogenes (3.2 $\pm 0.3 \log \mathrm{cfu} / \mathrm{mL}$ reduction), Salmonella spp. (3.7 $\pm 0.2 \log \mathrm{cfu} / \mathrm{mL}$ reduction), Escherichia coli (2.8 $\pm 0.2 \mathrm{log} \mathrm{cfu} / \mathrm{mL}$ reduction), Staph. aureus (3.4 \pm $0.3 \mathrm{log} \mathrm{cfu} / \mathrm{mL}$ reduction), Streptococcus spp. (3.4 \pm 0.4 $\log \mathrm{cfu} / \mathrm{mL}$ reduction), and A. baumannii (2.8 $\pm 0.2 \log$ $\mathrm{cfu} / \mathrm{mL}$ reduction). The UVC treatment of milk did not result in a significant final count $(\log \mathrm{cfu} / \mathrm{mL})$ reduction for $M$. smegmatis $(1.8 \pm 0.5 \log \mathrm{cfu} / \mathrm{mL}$ reduction). The UVC treatment of colostrum was significantly associated with a final reduction of bacterial count (log cfu/ $\mathrm{mL})$ of Listeria spp. (1.4 $\pm 0.3 \mathrm{log} \mathrm{cfu} / \mathrm{mL}$ reduction), Salmonella spp. (1.0 $\pm 0.2 \log \mathrm{cfu} / \mathrm{mL}$ reduction $)$, and Acinetobacter spp. (1.1 $\pm 0.3 \mathrm{log} \mathrm{cfu} / \mathrm{mL}$ reduction $)$, but not of $E$. coli $(0.5 \pm 0.3 \mathrm{log} \mathrm{cfu} / \mathrm{mL}$ reduction $)$, Strep. agalactiae $(0.8 \pm 0.2 \log \mathrm{cfu} / \mathrm{mL}$ reduction $)$, and
\end{abstract}

Received October 14, 2013.

Accepted January 8, 2014.

${ }^{1}$ Corresponding author: rcb28@cornell.edu
Staph. aureus $(0.4 \pm 0.2 \log \mathrm{cfu} / \mathrm{mL}$ reduction). The UVC treatment of colostrum significantly decreased the IgG concentration, with an observed final mean IgG reduction of approximately $50 \%$. Development of new methods to reduce bacterial contaminants in colostrum must take into consideration the barriers imposed by its opacity and organic components, and account for the incidental damage to IgG caused by manipulating colostrum.

Key words: ultraviolet light, colostrum, immunoglobulin G, milk

\section{INTRODUCTION}

Feeding preweaned calves raw milk and colostrum has the potential to increase calf morbidity and mortality due to ingestion of pathogenic agents. Some important pathogenic bacteria identified in raw milk and colostrum include Listeria monocytogenes, Salmonella spp., Escherichia coli, Mycobacterium avium subspecies paratuberculosis (MAP), Staphylococcus aureus, and Streptococcus spp. (Elizondo-Salazar and Heinrichs, 2009; Oikonomou et al., 2012; Pearce et al., 2012).

Pasteurization is commonly used on dairy farms as an effective preventive method to reduce bacterial load in the milk fed to calves. However, pasteurization is an energy-demanding process with high capital and operating costs (Krishnamurthy et al., 2004). Heat treatment of colostrum at a high temperature for a short time has been associated with a decrease in IgG concentration of 22 to $27 \%$ (Stabel et al., 2004). However, heat treatment of colostrum at a lower temperature $\left(60^{\circ} \mathrm{C}\right)$ for 60 min has been observed to have no significant changes in the IgG concentration compared with raw colostrum and has been suggested as a viable option for treatment of colostrum at the dairy farm (Johnson et al., 2007; Donahue et al., 2012).

The classical use of UV light has occurred in biological safety cabinets in laboratories, although in recent years its use has been extended to inactivation of microorganisms in the food-processing industry, in potable water, and in wastewater (Gómez et al., 2011). Ultraviolet light inactivates microorganisms by form- 
Table 1. Bacterial species, strain identification (ID), and description of bacteria used to inoculate whole milk and colostrum

\begin{tabular}{lll}
\hline Bacteria & Strain ID & Description ${ }^{1}$ \\
\hline Gram-negative bacteria & & \\
Salmonella Typhimurium & ATCC 14028 & ATCC strain \\
Salmonella Typhimurium & N001 & Resistance to AMPI/KAN/STR/STX/TET \\
Salmonella Typhimurium & MDR001 & Resistance CRO/CHL/NAL/TET/STR \\
Escherichia coli & ATCC 25922 & ATCC strain \\
E. coli & $34405-1$ & Resistance to STX/TET/AMPI/STR and EAEC \\
E. coli & $34583-1$ & EAEC/EHEC and resistance to CEFT/AMC/STX/TET/AMPI/STR \\
Acinetobacter baumannii & ATCC 19606 & ATCC strain \\
A. baumannii & 4628 & Resistance to AK/AMS \\
A. baumannii & 5076 & Resistance to AK \\
Gram-positive bacteria & & \\
Staphylococcus aureus & ATCC 27708 & ATCC strain \\
Staph. aureus & 5445 & Methicillin-resistant Staph. aureus (MRSA) \\
Staph. aureus & 5480 & MRSA \\
Streptococcus agalactiae & SAG2 & Resistant to STX \\
Strep. agalactiae & SAG18 & Resistant to STX \\
Listeria innocua & ATCC 33090 & ATCC strain and surrogate for Listeria monocytogenes \\
Mycobacterium smegmatis & mc2155 & Surrogate for Mycobacterium avium ssp. paratuberculosis
\end{tabular}

${ }^{1} \mathrm{AK}=$ amikacin; AMC, amoxicillin-clavulanic acid; AMPI = ampicillin; AMS = ampicillin-sulbactam; ATCC = American Type Culture Collection; $\mathrm{CEFT}=$ ceftiofur; $\mathrm{CHL}=$ chloramphenicol; $\mathrm{CRO}=$ ceftriaxone; EAEC $=$ enteroaggregative $E$. coli; EHEC $=$ enterohemorrhagic $E$. coli KAN = kanamycin; NAL = nalidixic acid; STR = streptomycin; STX = sulfamethoxazole-trimethoprim; TET = tetracycline.

ing pyrimidine dimers in RNA and DNA, which can interfere with transcription and replication (Goosen and Moolenaar, 2008; Cutler and Zimmerman, 2011). The germicidal effect of UV light treatment is dependent on microbial exposure, but when used on opaque foods with irregular surfaces, UV light may cause less microbial destruction. Although the opacity and high absorption coefficient of milk has been considered a barrier to the use of UV light as a disinfectant, UV light treatment of milk has been shown to reduce bacterial counts of L. monocytogenes in goat milk and Staph. aureus in cow milk (Matak et al., 2005).

Therefore, the objectives of this study were to determine the effect of UV light treatment on the count (log $\mathrm{cfu} / \mathrm{mL}$ ) reduction of bacteria (Listeria innocua, Mycobacterium smegmatis, Salmonella serovar Typhimurium, E. coli, Staph. aureus, Streptococcus agalactiae, and Acinetobacter baumannii) inoculated into sterile milk and colostrum, and on IgG concentration in colostrum.

\section{MATERIALS AND METHODS}

\section{Bacteria for Inoculation of Milk and Colostrum}

Seven bacterial species of concern to animal and human health were selected as inoculants in the milk trials: L. innocua, M. smegmatis, Salmonella serovar Typhimurium, E. coli, Staph. aureus, Strep. agalactiae, and A. baumannii. For Salmonella spp., E. coli, Staph. aureus, Strep. agalactiae, and A. baumannii, 2 to 3 different strains were selected for inoculation of milk (Table 1). For the remaining bacterial species, only 1 strain was selected for inoculation of milk. Listeria in- nocua and $M$. smegmatis were chosen as surrogates for L. monocytogenes and MAP, respectively (Bannantine et al., 1997; Friedly et al., 2008). For the colostrum experiments, only 1 strain of L. innocua [American Type Culture Collection (ATCC) 33090], Salmonella serovar Typhimurium (ATCC 14028), E. coli (ATCC 25922), Staph. aureus (ATCC 27708), Strep. agalactiae (SAG 2), and A. baumannii (ATCC 19606) were chosen as inoculants (Table 1).

\section{Preparation of Cell Suspension}

Each bacterial strain was cultured individually on growth medium specific for the species, following the manufacturers' instructions (Table 2). Briefly, bacterial stocks stored at $-80^{\circ} \mathrm{C}$ were transferred using an inoculation loop into broth growth medium and grown under conditions ideal for each bacterial species, as described in Table 2. After incubation, a bacterial pellet was harvested from the broth growth medium by centrifugation $(4,000 \times g$ for $22 \mathrm{~min})$ and resuspended in broth medium to create bacteria stocks by pipetting $800 \mu \mathrm{L}$ of the solution into Eppendorf tubes containing $200 \mu \mathrm{L}$ of $80 \%$ glycerol. Bacterial stocks were stored at $-80^{\circ} \mathrm{C}$ until used for inoculation of milk and colostrum (Perez et al., 2003; Altic et al., 2007; Hegde et al., 2007; Choi et al., 2008; Nicolaou et al., 2011).

\section{Pilot-Scale UV Light Machine}

The experimental device tested consisted of a pilotscale UV light continuous (UVC) flow-through unit (GEA Farm Technologies, Naperville, IL), with turbu- 
Table 2. Bacterial species culture media and growth conditions

\begin{tabular}{|c|c|c|}
\hline Bacterial species & Broth culture media and growth conditions ${ }^{1}$ & $\begin{array}{l}\text { Recovery and enumeration media } \\
\text { and growth conditions }{ }^{2}\end{array}$ \\
\hline Salmonella Typhimurium & $\mathrm{LB}$ broth for $24 \mathrm{~h}$ at $37^{\circ} \mathrm{C}$ (Barrow et al., 1996) & CHROMagar ${ }^{3}$ Salmonella for $24 \mathrm{~h}$ at $37^{\circ} \mathrm{C}$ \\
\hline Escherichia coli & LB broth for $24 \mathrm{~h}$ at $37^{\circ} \mathrm{C}$ (Zhang et al., 2011) & CHROMagar E. coli for $24 \mathrm{~h}$ at $37^{\circ} \mathrm{C}$ \\
\hline Staphylococcus aureus & $\mathrm{LB}$ broth for $24 \mathrm{~h}$ at $37^{\circ} \mathrm{C}$ (Zhang et al., 2011) & CHROMagar Staphylococcus for $24 \mathrm{~h}$ at $37^{\circ} \mathrm{C}$ \\
\hline Streptococcus agalactiae & $\mathrm{BHI}$ broth for $24 \mathrm{~h}$ at $37^{\circ} \mathrm{C}$ (Viazis et al., 2008) & CHROMagar StrepB for $24 \mathrm{~h}$ at $37^{\circ} \mathrm{C}$ \\
\hline Listeria innocua & $\mathrm{BHI}$ broth for $24 \mathrm{~h}$ at $37^{\circ} \mathrm{C}$ (Viazis et al., 2008) & CHROMagar Listeria for $48 \mathrm{~h}$ at $37^{\circ} \mathrm{C}$ \\
\hline
\end{tabular}

${ }^{1} \mathrm{LB}=$ Luria-Bertani broth; $\mathrm{BHI}=$ brain-heart infusion broth.

${ }^{2} \mathrm{MB}=$ Middlebrook culture media; $\mathrm{ADC}=$ oleic acid-albumin-dextrose-catalase.

${ }^{3}$ CHROMagar, Paris, France.

lators made of stainless steel, a pump unit for fluids (flow rate of $65 \mathrm{l} / \mathrm{min} ; 230-\mathrm{V}$ pump with 20 -A breaker), and $1 \mathrm{UV}$ lamp module $\left(45 \mathrm{~J} / \mathrm{cm}^{2}\right.$; dimensions: $610 \mathrm{~mm}$ wide, 1,665 $\mathrm{mm}$ long, and $500 \mathrm{~mm}$ deep). The UV lamp was inserted into a transparent quartz tube to allow exposure of the milk to the UV light (Figure 1). The time necessary for a batch of $4 \mathrm{~L}$ of milk or colostrum to fully flow through the UVC unit was 2 min and $30 \mathrm{~s}$.

\section{Sample Preparation and Inoculation}

Commercial pasteurized-homogenized whole milk (3.25\% fat content) was purchased at a local supermarket and autoclaved $\left(121^{\circ} \mathrm{C}\right.$ for $\left.32 \mathrm{~min}\right)$ before inoculation with bacteria. Two different bacteria-inoculated milk batches were used, and their bacterial composition and mean concentration ( $\log \mathrm{cfu} / \mathrm{mL})$ in the milk before initializing the UV light treatment were (1) milk inoculated with only $M$. smegmatis $(4.7 \pm 0.5 \log \mathrm{cfu} / \mathrm{mL})$

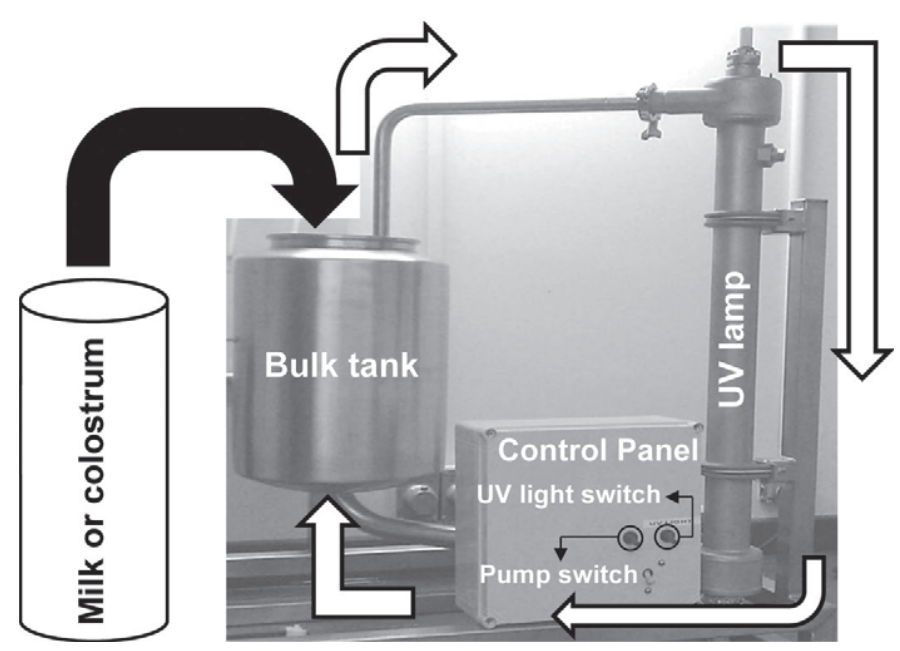

Figure 1. Flow-through UV light unit used for trials. White arrows indicate the continuous flow trajectory of fluids through the UV lamp and returning to the bulk tank when the pump was switched on. and (2) milk inoculated with a bacterial cocktail made from combining 1 strain of L. innocua $(7.6 \pm 0.2 \log$ $\mathrm{cfu} / \mathrm{mL})$, Salmonella serovar Typhimurium $(7.4 \pm 0.2$ $\log \mathrm{cfu} / \mathrm{mL})$, E. coli $(6.2 \pm 0.2 \log \mathrm{cfu} / \mathrm{mL})$, Staph. aureus $(7.3 \pm 0.2 \log \mathrm{cfu} / \mathrm{mL})$, Strep. agalactiae $(5.2 \pm 0.3$ $\log \mathrm{cfu} / \mathrm{mL})$, and A. baumannii $(6.4 \pm 0.2 \log \mathrm{cfu} / \mathrm{mL})$. Mycobacterium smegmatis was inoculated in a separate batch to increase the precision of the enumeration on the selective growth media. For Salmonella spp., E. coli, Staph. aureus, Strep. agalactiae, and A. baumannii, 2 to 3 different strains were selected for inoculation of milk, and to compare the effects of UVC on each individual strain, sterile milk batches were inoculated with only 1 bacterial strain belonging to the same bacterial species at a time. Four repetitions were performed for each bacterial strain and each bath contained $4 \mathrm{~L}$ of milk.

Raw colostrum pooled from multiple cows was obtained from a nearby dairy farm. Colostrum used in the study was not autoclaved. Raw colostrum used to evaluate the effect of UVC on bacterial contaminants was inoculated with a bacterial cocktail composed of 1 bacterial strain. The bacterial strains selected and the mean concentration $(\log \mathrm{cfu} / \mathrm{mL})$ in the colostrum for these bacteria species before initializing the UV light treatment were Listeria spp. (strain ATCC 33090; $4.6 \pm$ $0.2 \log \mathrm{cfu} / \mathrm{mL}$ ), Salmonella spp. (strain ATCC 14028; $7.6 \pm 0.2 \log \mathrm{cfu} / \mathrm{mL}$ ), E. coli (strain ATCC 25922; 6.7 $\pm 0.3 \log \mathrm{cfu} / \mathrm{mL}$ ), Staph. aureus (strain ATCC 27708; $7.8 \pm 0.1 \log \mathrm{cfu} / \mathrm{mL}$ ), Strep. agalactiae (strain SAG 2; $3.7 \pm 0.2 \log \mathrm{cfu} / \mathrm{mL}$ ), and Acinetobacter spp. (strain ATCC 19606; $5.0 \pm 0.2 \log \mathrm{cfu} / \mathrm{mL}$; (Table 1). Four repetitions where performed for each bacterial species and each bath contained $4 \mathrm{~L}$ of colostrum.

\section{Testing the Effect of UVC on Bacterial Counts}

To evaluate the ability of UVC treatment to reduce bacterial counts in milk and colostrum, samples were collected at 5 time points: (1) UV lamp and pump both 
off and after mixing the milk or colostrum manually with a sterile rod for 1 min (OFF), (2) UV lamp off and after the pump had been on for 2 min and $30 \mathrm{~s}(40$ cycles; PT), (3) UV lamp on and after the pump had been on for 2 min and $30 \mathrm{~s}$ (40 cycles; T1), (4) UV lamp on and after the pump had been on for 5 min $(80$ cycles; T2), and (5) UV lamp on and after the pump had been on for 7 min and $30 \mathrm{~s}$ (120 cycles; T3; Figure 2). Samples OFF and PT were collected before any exposure to UV light with the aim of evaluating the effect of the pump alone on bacterial contaminants. When collecting UV light-exposed samples (T1, T2, and T3), the UV lamp was switched on for 5 min before switching on the pump, allowing the UV lamp to achieve an optimal activity level.

\section{UVC Unit Cleaning Protocol}

Between milk or colostrum batches, a 5-step cleaning protocol was implemented for the UVC unit as follows: (1) rinsed with $6 \mathrm{~L}$ of warm water and sodium hypochlorite (The Clorox Co., Oakland, CA) for 5 min, (2) rinsed with $4 \mathrm{~L}$ of warm water and an alkaline detergent (TRI-PFAN; GEA Farm Technologies) for 5 min,
(3) rinsed with $4 \mathrm{~L}$ of warm water and a low-foam acid cleaner (LAC; GEA Farm Technologies) for 3 min, (4) rinsed with $8 \mathrm{~L}$ of warm water and sodium hypochlorite (The Clorox Co.) for $3 \mathrm{~min}$, and (5) rinsed with $4 \mathrm{~L}$ of hot water $\left(>75^{\circ} \mathrm{C}\right)$ for $3 \mathrm{~min}$.

\section{Microbiology Assays}

Both milk and colostrum samples were serially diluted $\left(10^{-1}\right.$ to $\left.10^{-8}\right)$ and $20-\mu \mathrm{L}$ aliquots were plated and incubated aerobically using selective media and conditions specific for each bacterial species (Table 2). An estimate of the colony-forming units per milliliter was made by calculating the average number of colonies (from triplicate determinations) and multiplying this number by the reciprocal of the dilution factor.

\section{Testing the Effect of UVC on Colostrum IgG}

Raw colostrum pooled from multiple cows was obtained from a nearby dairy farm. Colostrum used in the study was not autoclaved. To evaluate the effect of UVC on colostrum IgG, samples were collected at 7 time points: (1) UV lamp and pump both off and after

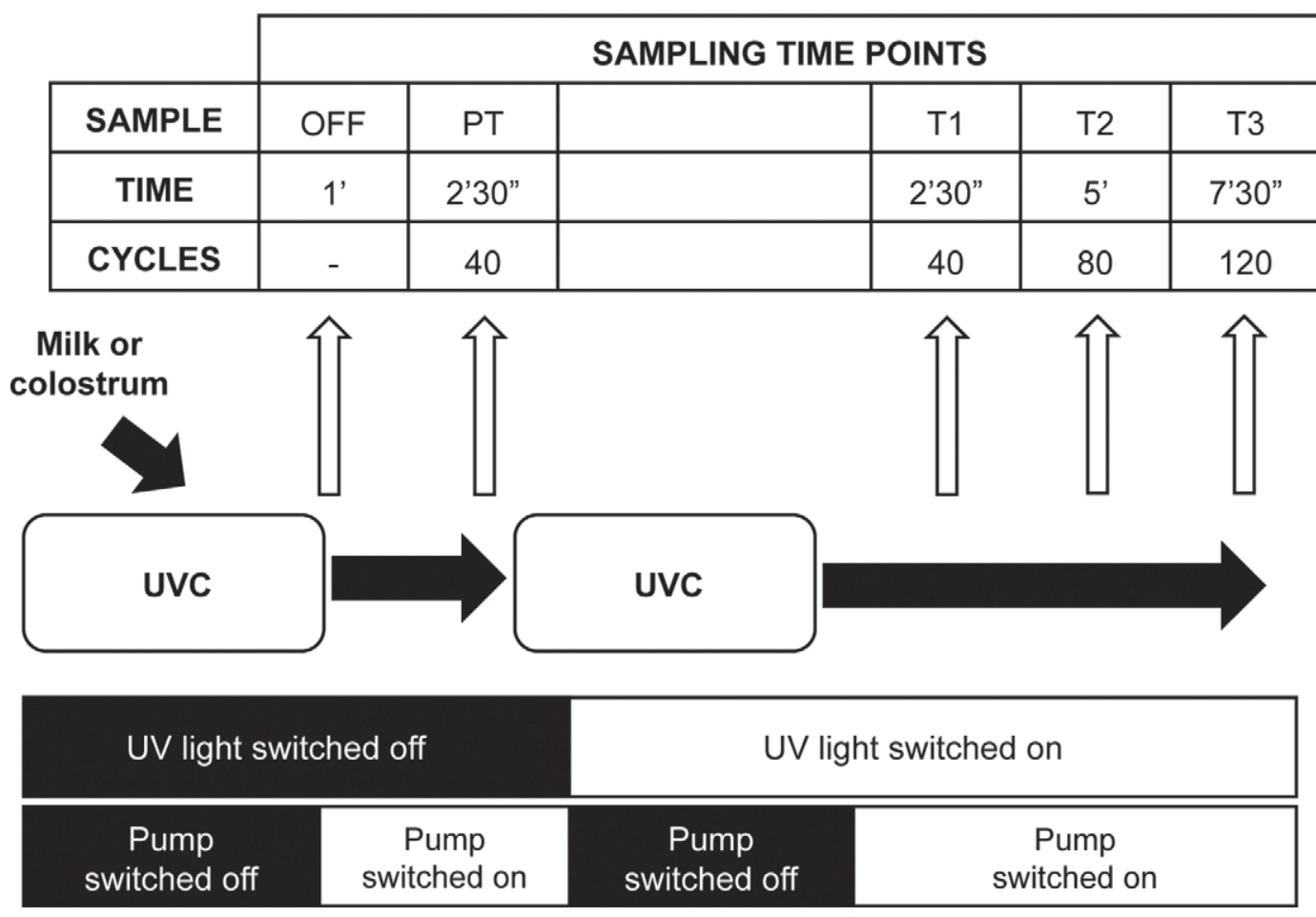

Figure 2. Ultraviolet light continuous (UVC) flow-through unit operation and description of exposure time and number of cycles the entire sample flowed through the UVC system before sample collection. To evaluate the ability of UVC treatment to reduce bacterial counts in milk and colostrum, samples were collected at 5 time points: (1) UV lamp and pump both off and after mixing the milk or colostrum manually with a sterile rod for $1 \mathrm{~min}$ (OFF), (2) UV lamp off and after the pump had been on for 2 min and $30 \mathrm{~s}$ (PT), (3) UV lamp on and after the pump had been on for 2 min and $30 \mathrm{~s}$ (T1), (4) UV lamp on and after the pump had been on for 5 min (T2), and (5) UV lamp on and after the pump had been on for $7 \mathrm{~min}$ and $30 \mathrm{~s}$ (T3). 
mixing the colostrum manually for $1 \mathrm{~min}(\mathrm{OFF}),(2)$ UV lamp off and after the pump had been on for $2 \mathrm{~min}$ and $30 \mathrm{~s}$ (40 cycles; PT), (3) UV lamp on and after the pump had been on for 2 min and $30 \mathrm{~s}$ (40 cycles; T1), (4) UV lamp on and after the pump had been on for 5 min (80 cycles; T2), (5) UV lamp on and after the pump had been on for 7 min and $30 \mathrm{~s}$ (120 cycles; T3), (6) UV lamp on and after the pump had been on for 10 min (160 cycles; T4), and (7) UV lamp on and after the pump had been on for 12 min and $30 \mathrm{~s}$ (200 cycles; T5). When collecting UV light-exposed samples (T1, T2, T3, T4, and T5), the UV lamp was switched on for 5 min before switching on the pump, allowing the UV lamp to achieve an optimal activity level. Because of the limited research on the effects of treatment of colostrum with UV light, a longer UVC exposure time of colostrum (up to T5 instead of only T3) was used, with the objective of obtaining additional information on the cumulative incidental effects of UV light on colostrum IgG. In total, 9 repetitions were performed and each bath contained $4 \mathrm{~L}$ of colostrum. Immunoglobulin G levels were quantified using ELISA (Immuno-Tek Bovine IgG ELISA Kit; ZeptoMetrix Corp., Buffalo, NY).

\section{Statistical Analysis}

Microbial counts $(\mathrm{cfu} / \mathrm{mL})$ were converted into logarithmic units for statistical analysis. The effect on milk and colostrum of flowing through the UVC pump in the absence of UV irradiation was tested by observing the variance of bacterial count $(\log \mathrm{cfu} / \mathrm{mL})$ from samples at OFF and PT by using ANOVA in the statistical software SAS (SAS Institute Inc., Cary, NC).

To evaluate the effect of UV light treatment on bacterial species added to sterile milk and to colostrum, for each bacteria species, a mixed linear model accounting for repeated measures (batches) was used (PROC MIXED; SAS Institute Inc.). In this model, the dependent variable was the count $(\log \mathrm{cfu} / \mathrm{mL})$ for the bacterial species and the independent variable was the sampling time points (PT, T1, T2, and T3). For bacteria species where more than 1 bacterial strain was used, an explanatory variable accounting for each individual bacterial strains and its interaction with sampling time points (PT, T1, T2, and T3) was added and retained in the model if the interaction was significant. A Tukey honestly significant difference (HDS) test was performed in SAS to identify pairs of sampling time points that had significantly different mean count (log $\mathrm{cfu} / \mathrm{mL}$ ) of each bacterial species tested.

The PROC REG procedure in SAS was used to complete a simple linear regression to evaluate the effect of UVC on colostrum IgG. IgG measured in colostrum was offered to the model as the dependent variable and the 7 sampling time points (OFF, MIX, T1, T2, T3, $\mathrm{T} 4$ and $\mathrm{T} 5$ ) were offered as independent variables. To illustrate the linear association of colostrum $\operatorname{IgG}$ and treatment by UVC, a simple linear scatter plot was computed using MedCalc Version 12.4.0.0 (MedCalc Software, Mariakerke, Belgium). All statistical models, variables and their interactions were considered significant when their respective $P$-values were $<0.05$.

\section{RESULTS}

\section{Effect of UVC on Bacterial Contaminants in Milk Samples}

The UVC treatment of milk resulted in a significant count $(\log \mathrm{cfu} / \mathrm{mL})$ reduction at T3 for L. monocytogenes $(3.2 \pm 0.35 \log \mathrm{cfu} / \mathrm{mL}$ reduction), Salmonella spp. $(3.7 \pm 0.27 \log \mathrm{cfu} / \mathrm{mL}$ reduction $)$, E. coli $(2.8$ $\pm 0.22 \log \mathrm{cfu} / \mathrm{mL}$ reduction), Staph. aureus (3.4 \pm $0.28 \log \mathrm{cfu} / \mathrm{mL}$ reduction), Streptococcus spp. (3.4 \pm $0.45 \log \mathrm{cfu} / \mathrm{mL}$ reduction), and A. baumannii ( $2.8 \pm$ $0.24 \log \mathrm{cfu} / \mathrm{mL}$ reduction). However, UVC treatment of milk did not result in a significant count (log cfu/ $\mathrm{mL})$ reduction at $\mathrm{T} 3$ for $M$. smegmatis $(1.8 \pm 0.5 \mathrm{log}$ $\mathrm{cfu} / \mathrm{mL}$ reduction; $P=0.07$; Figure 3 ). No significant difference was observed in the bacterial count (log cfu/ $\mathrm{mL}$ ) from OFF to PT for all milk trials (UV light was switched off during these 2 sampling points). No significant difference in the bacterial count $(\log \mathrm{cfu} / \mathrm{mL})$ at different time points was observed at the bacterial species level between strains of Salmonella spp., E. coli, Staph. aureus, Strep. agalactiae, and A. baumannii, for which more than 1 strain per bacterial species was used to inoculate distinct sterile milk batches.

\section{Effect of UVC on Bacterial Contaminants and IgG in Colostrum Samples}

Although increasing the number of cycles that the colostrum was exposed to UVC radiation lowered the count $(\log \mathrm{cfu} / \mathrm{mL})$ for all 6 bacterial species tested, the UVC treatment of colostrum was significantly associated with a count $(\log \mathrm{cfu} / \mathrm{mL})$ reduction at T3 of Listeria spp. (1.4 $\pm 0.3 \mathrm{log} \mathrm{cfu} / \mathrm{mL}$ reduction), Salmonella spp. (1.0 $\pm 0.2 \log \mathrm{cfu} / \mathrm{mL}$ reduction), and Acinetobacter spp. (1.1 $\pm 0.3 \log \mathrm{cfu} / \mathrm{mL}$ reduction), but not of E. coli (0.5 $\pm 0.3 \log \mathrm{cfu} / \mathrm{mL}$ reduction), Strep. agalactiae $(0.8 \pm 0.2 \log \mathrm{cfu} / \mathrm{mL}$ reduction), and Staph. aureus (0.4 $\pm 0.2 \mathrm{log} \mathrm{cfu} / \mathrm{mL}$ reduction; Figure 4$)$. No significant difference was observed in the $\log \mathrm{cfu} / \mathrm{ml}$ for any of the 6 bacterial species tested from OFF to PT.

Treatment of colostrum with UVC had a negative linear association with IgG concentration in colostrum $(P=0.019$; Figure 5$)$. A mean IgG reduction of ap- 

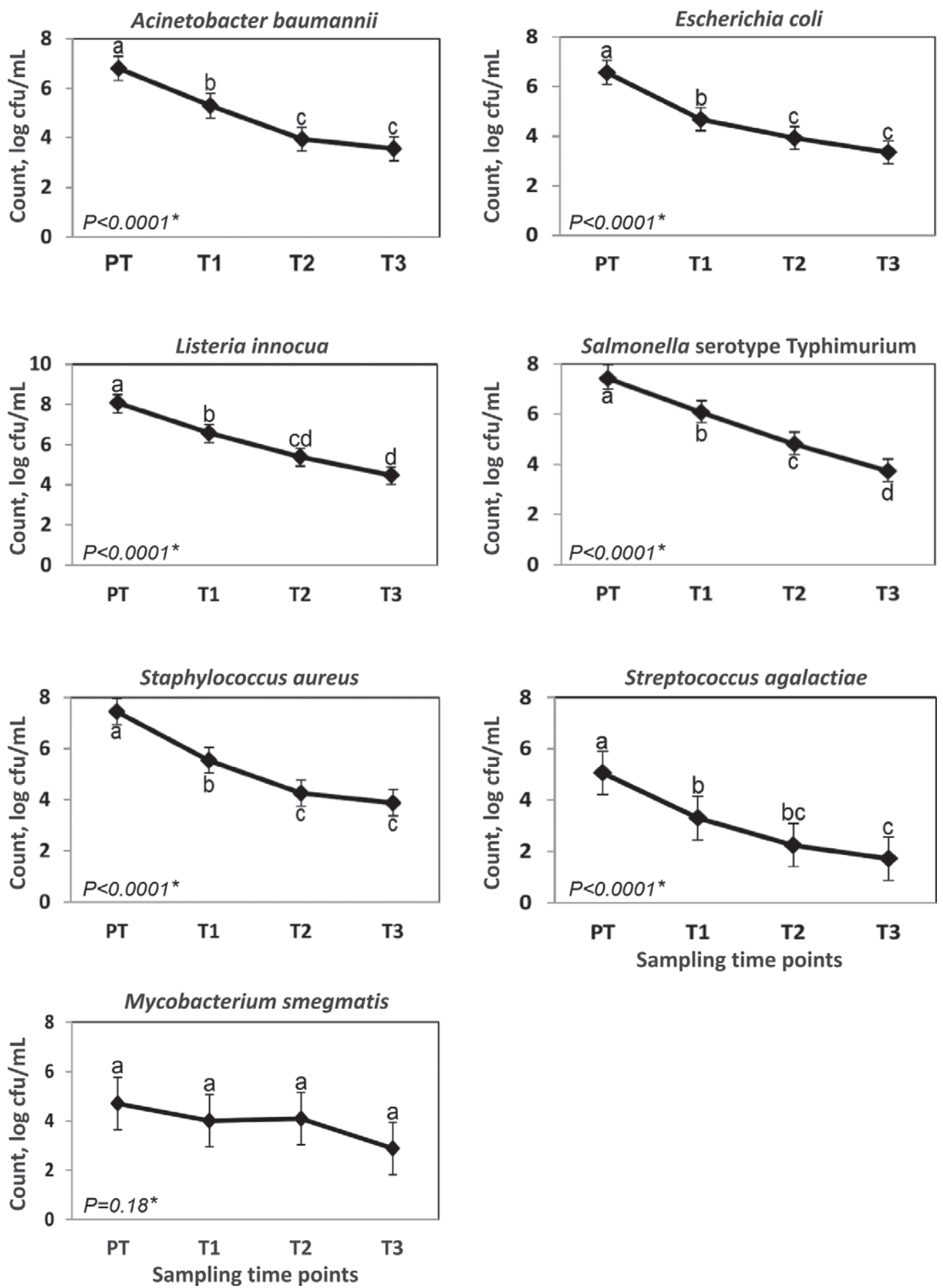

Figure 3. Counts (mean log cfu/mL) for milk samples after UV light continuous (UVC) treatment. Error bars correspond to a $95 \%$ confidence interval. Different letters $(\mathrm{a}-\mathrm{d})$ between time points within each graph indicate means that are statistically different $(P<0.05)$. Asterisks $\left.{ }^{*}\right)$ indicate $P$-values for the mixed linear model used to analyze the mean bacterial count $(\log \mathrm{cfu} / \mathrm{mL})$ difference between all sampling time points. PT $=$ UV lamp off and after the pump had been on for 2 min and $30 \mathrm{~s}$; T1 = UV lamp on and after the pump had been on for 2 min and $30 \mathrm{~s}$; T2 = UV lamp on and after the pump had been on for $5 \mathrm{~min}$; T3 = UV lamp on and after the pump had been on for $7 \mathrm{~min}$ and $30 \mathrm{~s}$. 

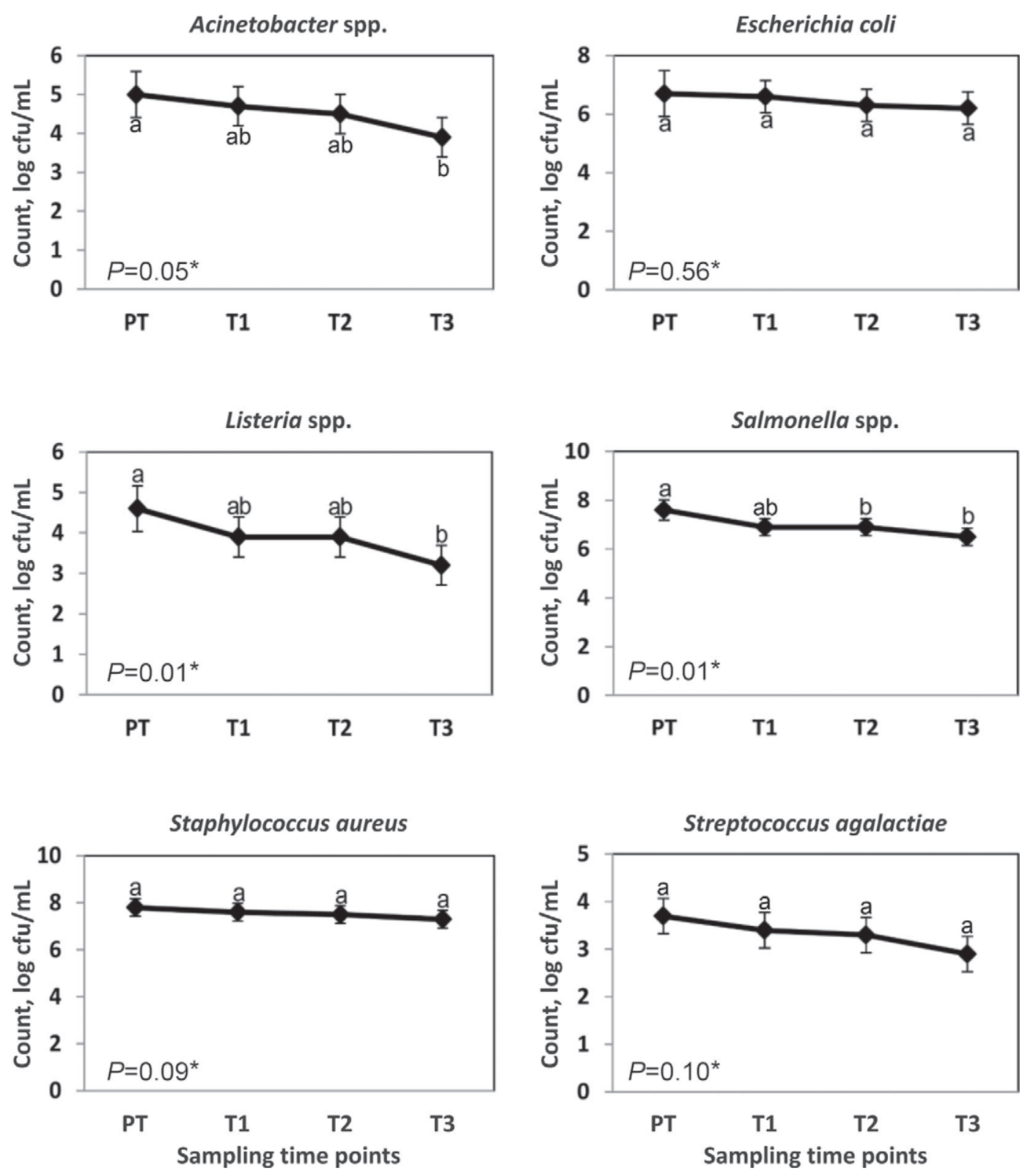

Figure 4. Counts (mean $\log \mathrm{cfu} / \mathrm{mL}$ ) for colostrum samples after UV light continuous (UVC) treatment. Error bars correspond to a $95 \%$ confidence interval. Different letters $(\mathrm{a}$ and $\mathrm{b})$ between time points within each graph indicate means that are statistically different $(P<0.05)$. Asterisks $(*)$ indicate $P$-values for the mixed linear model used to analyze the mean bacterial count $(\log \mathrm{cfu} / \mathrm{mL})$ difference between all sampling time points. PT $=$ UV lamp off and after the pump had been on for $2 \mathrm{~min}$ and $30 \mathrm{~s}$; T1 = UV lamp on and after the pump had been on for 2 min and $30 \mathrm{~s}$; T2 = UV lamp on and after the pump had been on for 5 min; T3 = UV lamp on and after the pump had been on for 7 min and $30 \mathrm{~s}$.

proximately $50 \%$ was observed from OFF $(70.5 \mathrm{~g} / \mathrm{L}$; $95 \% \mathrm{CI}=51-90 \mathrm{~g} / \mathrm{L})$ to $\mathrm{T} 5(35.1 \mathrm{~g} / \mathrm{L} ; 95 \% \mathrm{CI}=15-54$ $\mathrm{g} / \mathrm{L})$.

\section{DISCUSSION}

With the exception of $M$. smegmatis, a significant reduction in the count $(\log \mathrm{cfu} / \mathrm{mL}$ ) for all bacterial species tested was observed as the milk was treated with the UVC. The UVC used in the trials had the same UV light $\left(45 \mathrm{~J} / \mathrm{cm}^{2}\right)$ and followed the similar dosage protocol recommended for the UV Pure system (GEA Farm Technologies), a commercially available machine to treat milk using UV light. Similar to our findings, a field trial by Teixeira et al. (2013) using the UV Pure system to treat hospital milk from 1 dairy observed significant reductions in bacterial counts, with logarithmic reductions in bacterial colony counts for total bacterial 


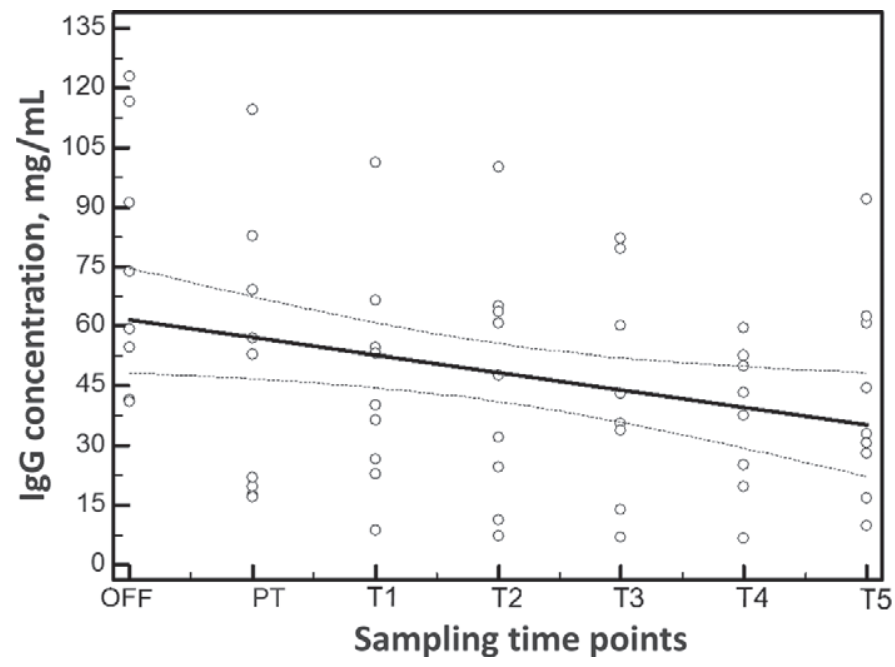

Figure 5. Simple linear scatter plot indicating the negative association of treatment of colostrum with UV light continuous (UVC) and IgG concentration $(P=0.019)$. A $95 \%$ confidence interval is delimited by the trace lines. To evaluate the effect of UVC on colostrum IgG, samples were collected at 7 time points: (1) UV lamp and pump both off and after mixing the milk or colostrum manually with a sterile rod for 1 min (OFF), (2) UV lamp off and after the pump had been on for 2 min and $30 \mathrm{~s}$ (PT), (3) UV lamp on and after the pump had been on for 2 min and $30 \mathrm{~s}$ (T1), (4) UV lamp on and after the pump had been on for 5 min (T2), (5) UV lamp on and after the pump had been on for $7 \mathrm{~min}$ and $30 \mathrm{~s}$ (T3), (6) UV lamp on and after the pump had been on for $10 \mathrm{~min}$ (T4), and (7) UV lamp on and after the pump had been on for $12 \mathrm{~min}$ and $30 \mathrm{~s}$ (T5).

count, E. coli, Staph. aureus, and Streptococcus spp. of $3.3,1.7,0.2$, and 2.0 , respectively. The same study also evaluated the pasteurization of hospital milk $\left(72^{\circ} \mathrm{C}\right.$ for $15 \mathrm{~s}$ ) and observed logarithmic reductions in bacterial colony counts for total bacterial count, E. coli, Staph. aureus, and Streptococcus spp. of 5.2, 1.2, 0.2, and 2.4, respectively (Teixeira et al., 2013). Teixeira et al. (2013) concluded that overall heat treatment of hospital milk was more effective than UV treatment in decreasing bacterial counts. A study by Matak et al. (2005) using a machine with 8 UV lamps $(254 \mathrm{~nm}$ and $90 \%$ emittance) observed a significant 5-log reduction of $L$. monocytogenes in UV-treated goat milk.

The lack of an effect of UV light on reduction of mycobacteria in milk identified in our study was also observed by Donaghy et al. (2009) when using a pilotscale UV light machine (30-W UVC output) to treat milk inoculated with MAP. They concluded that the apparent resistance of MAP to UV light treatment could have been caused by the opacity of milk and the recalcitrance of MAP to inimical treatments. Because MAP is a slow-growing mycobacterium which can have an incubation period for enumeration of colonies by solid culture of more than 3 mo, M. Smegmatis was chosen to be used as a surrogate in the current study (Grant et al., 2001; Kralik et al., 2012). Mycobacterium smegmatis is a fast-growing species of mycobacteria with no linkage to human disease, having dormancy genes similar to those in MAP (Whittington et al., 2004). Mycobacterium smegmatis has often been used as a surrogate for pathogenic bacteria such as Mycobacterium tuberculosis, Mycobacterium leprae, and MAP (Bannantine et al., 1997; Dhandayuthapani et al., 1997; Harris and Barletta, 2001; Chaturvedi et al., 2007).

In this study, UVC treatment of colostrum caused a significant reduction in the bacterial count (log cfu/ $\mathrm{mL}$ ) for Listeria spp., Salmonella spp., and Acinetobacter spp., but not of the remaining bacteria species. A study by Teixeira et al. (2013) observed an average logarithmic reduction in bacterial reduction in colostrum treated with a UV Pure system of 1.7, 2.2, 0.4, and 2.5 for the total bacterial count, E. coli, Staph. aureus, and Streptococcus spp., respectively. When using heat treatment of colostrum at $63^{\circ} \mathrm{C}$ for $60 \mathrm{~min}$ in the same study, they observed an average logarithmic reduction in bacterial reduction in colostrum of 3.5, 4.5, 0.4, and 2.5 for the total bacterial count, E. coli, Staph. aureus, and Streptococcus spp., respectively (Teixeira et al., 2013). Teixeira et al. (2013) concluded that the overall heat treatment of colostrum was more effective than UV treatment in decreasing bacterial counts. Additional research using the same settings as used in our study is needed to allow a direct comparison of efficacy on reduction of bacterial counts when using UVC or other available approaches to treat milk or colostrum.

The lack of a significant bacterial reduction of some of the bacteria species after treatment of colostrum with UVC may be explained by a limited penetrating ability of UV light in colostrum, causing a lower reduction in bacterial counts. Liquids that have high light transmissivity can be effectively treated with UV light, but liquids with low light transmissivity, caused by particulate materials or organic compounds, may pose a barrier for UV treatment (Guerrero-Beltrán and Barbosa-Cánovas, 2004). A common measurement to assess the penetration of UV light through fluids is the absorption coefficient (AC), where less penetration of light occurs with higher AC. As an example, the $\mathrm{AC}$ for drinking water is around 0.02 to $0.1\left(\mathrm{~cm}^{-1}\right)$, whereas the $\mathrm{AC}$ for milk is $300\left(\mathrm{~cm}^{-1}\right)$, which illustrates a limitation of using UV light on opaque fluids (Guerrero-Beltrán and Barbosa-Cánovas, 2004). The challenges of using UV light to irradiate colostrum are even greater than those observed for milk, considering that colostrum has, on average, higher quantities of organic compounds such as fat $(6.7 \%$ in colostrum vs. $4 \%$ in milk) and protein (14\% in colostrum vs. $3.1 \%$ in milk; Godden, 2008).

Added to the potential reduction in exposure of bacteria to UV radiation in the colostrum, another additional 
explanation for the significant reduction in the bacterial count $(\log \mathrm{cfu} / \mathrm{mL})$ for Listeria spp., Salmonella spp., and Acinetobacter spp. but not of the remaining bacteria species after treatment of colostrum samples with UVC could have been related to resistance of these bacteria species to UV radiation. Albarracín et al. (2012), who studied strains of Acinetobacter spp. isolated from ecosystems at high altitudes, observed strains resistant to high levels of UV radiation. The resistance of these strains was related in part to their ability to more effectively repair pyrimidine dimers compared with control strains. The mechanism of UV light inactivation of microorganisms is based on the formation of dimers in RNA and DNA, causing damage that can interfere with transcription and replication and, furthermore, cause bacterial death (Cutler and Zimmerman, 2011). Bacterial mechanisms to repair damage caused by UV light include direct reversal of the damage by a photolyase (photoreactivation), removal of the lesion by a DNA glycosylase, and nucleotide excision repair (Goosen and Moolenaar, 2008). Bacterial strains with more effective mechanisms of dimer repair could have lower count reductions in milk after exposure to UV light.

A negative linear relationship was observed between the duration of UVC treatment of colostrum and the concentration of IgG (Figure 5). A study by Teixeira et al. (2013) observed that colostrum treated with a commercial UV light flow-through machine caused a reduction in colostrum IgG of $42.2 \%$ compared with untreated colostrum. Although UVC was capable of significantly reducing the bacterial counts for Listeria spp., Salmonella spp., and Strep. agalactiae in colostrum, its use to treat colostrum fed to calves must be carefully considered and the potential loss of viable IgG taken into account. Colostrum IgG has been shown to be sensitive to pressure, heat, and acid, which affect the conformation of the immunoglobulin molecule and ultimately the immunological activity of the antibody (Hurley and Theil, 2011). Trujillo et al. (2007) observed that treatment of caprine colostrum at a pressure of 500 $\mathrm{MPa}$ caused a reduction in IgG of $40 \%$ compared with untreated colostrum. Heat treatment of colostrum has been shown to result in mean IgG losses as high as $24 \%$ after treatment at $63^{\circ} \mathrm{C}$ for $30 \mathrm{~min}$ (Meylan et al., 1996; Godden et al., 2003). However, recent studies have shown that heat treatment of colostrum at a slightly lower temperature $\left(60^{\circ} \mathrm{C}\right)$ for $60 \mathrm{~min}$ had no significant changes in the IgG concentration compared with raw colostrum and furthermore decreased colostrum total plate counts $\left(-2.25 \log _{10}\right)$ and coliform counts $(-2.49$ $\log _{10}$; Johnson et al., 2007; Donahue et al., 2012). Acidic $\mathrm{pH}$ has also been shown to cause denaturation and to reduce the antigen-binding activity of IgG in colostrum (Chen and Chang, 1998; Domínguez et al., 2001). Pro- cedures that have the purpose of reducing the bacterial load present in colostrum must take into account the resulting effects on the immunological activity of the antibodies.

\section{CONCLUSIONS}

The UVC treatment of sterile, commercial whole milk inoculated with bacteria caused a significant reduction for all bacterial species tested except M. smegmatis. The UVC treatment of colostrum samples inoculated with bacterial contaminants resulted in a significant reduction in the bacterial count at T3 for Listeria spp., Salmonella spp., and Acinetobacter spp., but not of $E$. coli, Strep. agalactiae, and Staph. aureus. Moreover, UVC treatment of colostrum lowered the concentration of IgG in colostrum in relation to the length of treatment duration. Processes that aim to reduce the bacterial count in colostrum must take into consideration the incidental effects on colostrum IgG.

\section{ACKNOWLEDGMENTS}

Research reported in this publication was partially supported by the National Center for Research Resources, a component of the National Institutes of Health (NIH, Bethesda, MD), under Award Number T32ODO011000. The content is solely the responsibility of the authors and does not necessarily represent the official views of the National Center for Research Resources or the National Institutes of Health. This study was also partially funded by GEA Farm Technologies (Naperville, IL), which manufactured the pilot-scale flow-through UV light unit (UV Pure system) used in the study to treat colostrum and milk. The funders had no role in study design, data collection and analysis, decision to publish, or preparation of the manuscript.

\section{REFERENCES}

Albarracín, V. H., G. P. Pathak, T. Douki, J. Cadet, C. D. Borsarelli, W. Gartner, and M. E. Farias. 2012. Extremophilic Acinetobacter strains from high-altitude lakes in Argentinean Puna: Remarkable UV-B resistance and efficient DNA damage repair. Orig. Life Evol. Biosph. 42:201-221.

Altic, L. C., M. T. Rowe, and I. R. Grant. 2007. UV light inactivation of Mycobacterium avium ssp. paratuberculosis in milk as assessed by FASTPlaqueTB phage assay and culture. Appl. Environ. Microbiol. 73:3728-3733.

Anuchin, A. M., A. L. Mulyukin, N. E. Suzina, V. I. Duda, G. I. El-Registan, and A. S. Kaprelyants. 2009. Dormant forms of $M y$ cobacterium smegmatis with distinct morphology. Microbiology 155:1071-1079.

Bannantine, J. P., R. G. Barletta, C. O. Thoen, and R. E. Andrews Jr. 1997. Identification of Mycobacterium paratuberculosis gene expression signals. Microbiology 143:921-928.

Barrow, P. A., M. A. Lovell, and L. Z. Barber. 1996. Growth suppression in early-stationary-phase nutrient broth cultures of Salmonella typhimurium and Escherichia coli is genus specific and not regulated by $\sigma^{\mathrm{S}}$. J. Bacteriol. 178:3072-3076. 
Chaturvedi, V., N. Dwivedi, R. P. Tripathi, and S. Sinha. 2007. Evaluation of Mycobacterium smegmatis as a possible surrogate screen for selecting molecules active against multi-drug resistant $\mathrm{Myco-}$ bacterium tuberculosis. J. Gen. Appl. Microbiol. 53:333-337.

Chen, C.-C., and H.-M. Chang. 1998. Effect of thermal protectants on the stability of bovine milk immunoglobulin G. J. Agric. Food Chem. 46:3570-3576.

Choi, C. H., J. S. Lee, Y. C. Lee, T. I. Park, and J. C. Lee. 2008. Acinetobacter baumannii invades epithelial cells and outer membrane protein A mediates interactions with epithelial cells. BMC Microbiol. 8:216.

Cutler, T. D., and J. J. Zimmerman. 2011. Ultraviolet irradiation and the mechanisms underlying its inactivation of infectious agents. Anim. Health Res. Rev. 12:15-23.

Dhandayuthapani, S., M. Mudd, and V. Deretic. 1997. Interactions of OxyR with the promoter region of the oxyR and $a h p C$ genes from Mycobacterium leprae and Mycobacterium tuberculosis. J. Bacteriol. 179:2401-2409.

Domínguez, E., M. D. Pérez, P. Puyol, L. Sanchez, and M. Calvo. 2001. Effect of $\mathrm{pH}$ on antigen-binding activity of $\mathrm{IgG}$ from bovine colostrum upon heating. J. Dairy Res. 68:511-518.

Donaghy, J., M. Keyser, J. Johnston, F. P. Cilliers, P. A. Gouws, and M. T. Rowe. 2009. Inactivation of Mycobacterium avium ssp. paratuberculosis in milk by UV treatment. Lett. Appl. Microbiol. 49:217-221.

Donahue, M., S. M. Godden, R. Bey, S. Wells, J. M. Oakes, S. Sreevatsan, J. Stabel, and J. Fetrow. 2012. Heat treatment of colostrum on commercial dairy farms decreases colostrum microbial counts while maintaining colostrum immunoglobulin $\mathrm{G}$ concentrations. J. Dairy Sci. 95:2697-2702.

Elizondo-Salazar, J. A., and A. J. Heinrichs. 2009. Feeding heat-treated colostrum to neonatal dairy heifers: Effects on growth characteristics and blood parameters. J. Dairy Sci. 92:3265-3273.

Friedly, E. C., P. G. Crandall, S. Ricke, C. A. O'Bryan, E. M. Martin, and L. M. Boyd. 2008. Identification of Listeria innocua surrogates for Listeria monocytogenes in hamburger patties. J. Food Sci. 73:M174-M178.

Godden, S. 2008. Colostrum management for dairy calves. Vet. Clin. North Am. Food Anim. Pract. 24:19-39.

Godden, S. M., S. Smith, J. M. Feirtag, L. R. Green, S. J. Wells, and J. P. Fetrow. 2003. Effect of on-farm commercial batch pasteurization of colostrum on colostrum and serum immunoglobulin concentrations in dairy calves. J. Dairy Sci. 86:1503-1512.

Gómez, P. L., J. Welti-Chanes, and S. M. Alzamora. 2011. Hurdle technology in fruit processing. Annu. Rev. Food Sci. Technol. $2: 447-465$.

Goosen, N., and G. F. Moolenaar. 2008. Repair of UV damage in bacteria. DNA Repair (Amst.) 7:353-379.

Grant, I. R., M. T. Rowe, L. Dundee, and E. Hitchings. 2001. Mycobacterium avium ssp. paratuberculosis: Its incidence, heat resistance and detection in milk and dairy products. Int. J. Dairy Technol. 54:2-13.

Guerrero-Beltrán, J., and G. Barbosa-Cánovas. 2004. Advantages and limitations on processing foods by UV light. Food Sci. Technol. Int. 10:137-147.

Harris, N. B., and R. G. Barletta. 2001. Mycobacterium avium ssp. paratuberculosis in veterinary medicine. Clin. Microbiol. Rev. 14:489-512.

Haydel, S. E., V. Malhotra, G. L. Cornelison, and J. E. Clark-Curtiss. 2012. The $\operatorname{pr} A B$ two-component system is essential for Mycobacterium tuberculosis viability and is induced under nitrogen-limiting conditions. J. Bacteriol. 194:354-361.

Hegde, V., C. G. Leon-Velarde, C. M. Stam, L.-A. Jaykus, and J. A. Odumeru. 2007. Evaluation of BBL CHROMagar Listeria agar for the isolation and identification of Listeria monocytogenes from food and environmental samples. J. Microbiol. Methods 68:82-87.

Hurley, W. L., and P. K. Theil. 2011. Perspectives on immunoglobulins in colostrum and milk. Nutrients 3:442-474.
Johnson, J. L., S. M. Godden, T. Molitor, T. Ames, and D. Hagman. 2007. Effects of feeding heat-treated colostrum on passive transfer of immune and nutritional parameters in neonatal dairy calves. J. Dairy Sci. 90:5189-5198.

Kralik, P., V. Beran, and I. Pavlik. 2012. Enumeration of Mycobacterium avium subsp. paratuberculosis by quantitative real-time PCR, culture on solid media and optical densitometry. BMC Res. Notes $5: 114$.

Krishnamurthy, K., A. Demirci, and J. Irudayaraj. 2004. Inactivation of Staphylococcus aureus by pulsed UV-light sterilization. J. Food Prot. 67:1027-1030

Matak, K. E., J. J. Churey, R. W. Worobo, S. S. Sumner, E. Hovingh, C. R. Hackney, and M. D. Pierson. 2005. Efficacy of UV light for the reduction of Listeria monocytogenes in goat's milk. J. Food Prot. 68:2212-2216.

Meylan, M., D. M. Rings, W. P. Shulaw, J. J. Kowalski, S. BechNielsen, and G. F. Hoffsis. 1996. Survival of Mycobacterium paratuberculosis and preservation of immunoglobulin $\mathrm{G}$ in bovine colostrum under experimental conditions simulating pasteurization. Am. J. Vet. Res. 57:1580-1585.

Nicolaou, N., Y. Xu, and R. Goodacre. 2011. Fourier transform infrared and Raman spectroscopies for the rapid detection, enumeration, and growth interaction of the bacteria Staphylococcus aureus and Lactococcus lactis ssp. cremoris in milk. Anal. Chem. 83:5681-5687.

Oikonomou, G., V. S. Machado, C. Santisteban, Y. H. Schukken, and R. C. Bicalho. 2012. Microbial diversity of bovine mastitic milk as described by pyrosequencing of metagenomic 16s rDNA. PLoS ONE $7: \mathrm{e} 47671$.

Pearce, L. E., B. W. Smythe, R. A. Crawford, E. Oakley, S. C. Hathaway, and J. M. Shepherd. 2012. Pasteurization of milk: The heat inactivation kinetics of milk-borne dairy pathogens under commercial-type conditions of turbulent flow. J. Dairy Sci. 95:20-35.

Perez, J. M., P. Cavalli, C. Roure, R. Renac, Y. Gille, and A. M. Freydiere. 2003. Comparison of four chromogenic media and Hektoen agar for detection and presumptive identification of Salmonella strains in human stools. J. Clin. Microbiol. 41:1130-1134.

Singh, A. K., and J. M. Reyrat. 2009. Laboratory maintenance of Mycobacterium smegmatis. Curr. Protoc. Microbiol. Chapter 10:Unit10C.1. http://dx.doi.org/10.1002/9780471729259. mc10c01s14.

Stabel, J. R., S. Hurd, L. Calvente, and R. F. Rosenbusch. 2004. Destruction of Mycobacterium paratuberculosis, Salmonella spp., and Mycoplasma spp. in raw milk by a commercial on-farm hightemperature, short-time pasteurizer. J. Dairy Sci. 87:2177-2183.

Teixeira, A. G. V., M. L. S. Bicalho, V. S. Machado, G. Oikonomou, C. Kacar, C. Foditsch, R. Young, W. A. Knauer, D. V. Nydam, and R. C. Bicalho. 2013. Heat and ultraviolet light treatment of colostrum and hospital milk: Effects on colostrum and hospital milk characteristics and calf health and growth parameters. Vet. J. 197:175-181.

Trujillo, A. J., N. Castro, J. M. Quevedo, A. Argüello, J. Capote, and B. Guamis. 2007. Effect of heat and high-pressure treatments on microbiological quality and immunoglobulin G stability of caprine colostrum. J. Dairy Sci. 90:833-839.

Viazis, S., B. E. Farkas, and L. A. Jaykus. 2008. Inactivation of bacterial pathogens in human milk by high-pressure processing. J. Food Prot. 71:109-118.

Whittington, R. J., D. J. Marshall, P. J. Nicholls, I. B. Marsh, and L. A. Reddacliff. 2004. Survival and dormancy of Mycobacterium avium subsp. paratuberculosis in the environment. Appl. Environ. Microbiol. 70:2989-3004.

Zhang, H., D. Li, S. Zhu, F. Feng, and X. Zheng. 2011. Antibacterial activities of a food-grade dilution-stable microemulsion. J. Food Saf. 31:232-237. 